\title{
Short-Term Price Effects of Stock Repurchases in Turkish Capital
} Markets

\author{
Burak Pirgaip ${ }^{1} \&$ Semra Karacaer ${ }^{2}$ \\ ${ }^{1}$ Capital Markets Board of Turkey, Sermaye Piyasası Kurulu, Ankara, Turkey \\ ${ }^{2}$ Department of Business Administration, Hacettepe University, Ankara, Turkey \\ Correspondence: Burak Pirgaip, Capital Markets Board of Turkey, Sermaye Piyasası Kurulu, Eskişehir Yolu \\ 8.km No: 156, 06530 Ankara, Turkey. Tel: 90-312-292-8412. E-mail: burak.pirgaip@ gmail.com
}

Received: September 5, 2015

Accepted: September 30, 2015

Online Published: November 25, 2015

doi:10.5539/ijef.v7n12p29

URL: http://dx.doi.org/10.5539/ijef.v7n12p29

\begin{abstract}
Stock repurchase, as a corporate finance tool and a substitute for cash dividends, plays an important role in distributing excess cash. Following a prohibited period due to its potentially negative outcomes for shareholders and creditors, stock repurchase has recently been regulated within the company law systems of many countries pursuant to its increasing popularity in satisfying special financing requirements of companies. That the regulatory improvements have removed the uncertainty inherent in such transactions has increased the volume of, especially, the open market stock repurchases. Turkish legislation, i.e. Commercial Code and Capital Markets $L a w$, has latterly been updated in accordance with EU acquis communautaire in order to allow stock repurchase for listed firms. We analyse movements in stock prices after stock repurchase transactions in order to make inferences about why stock repurchase is used and what its impacts/signals are in Turkish market at their infancy stage. Having followed a standard event study methodology, the results reveal that investor reaction to stock repurchase transactions is generally positive in the short-term. These results support the notion of a signaling hypothesis as a motivator behind stock repurchase decisions.
\end{abstract}

Keywords: stock repurchase, abnormal returns, signaling, event study, stock prices

\section{Introduction}

Stock repurchase has become a common practice in global capital markets, especially in the US. For instance, repurchase transactions of Standard \& Poor's 500 listed companies have been amounted to \$197 billion, \$349 billion and \$437 billion in 2004, 2005 and 2006 respectively (MacGuigan, Kretlow, \& Moyer, 2009, p. 528). Repurchase transactions are common in other markets either, especially in Anglo-Saxon jurisdictions. Canada is the second biggest market where repurchases occur (De Jong, van Dijk, \& Veld, 2003, p. 350). In fact, the amount of repurchases in 2003 has been increased to $\$ 3.3$ billion from its $\$ 429$ million level in 1985 (Kooli \& L'Her, 2010). Total consideration paid for repurchases in the UK has reached $£ 46$ billion as of 2006 (Dhanani \& Roberts, 2009, p. VII). Even in Continental Europe jurisdictions where repurchases had been prohibited for years have recently allowed these transactions. The amount of repurchase transactions has reached $€ 3.5$ billion in Germany and $€ 6.2$ billion in France (Mieczysław, 2011, p. 50). Repurchase transactions have become popular also in Far East countries like Japan, Hong Kong, Thailand; in Scandinavian countries like Swed en, Denmark, Norway; and, Latin America countries like Brazil and Mexico.

Companies have the intention to repurchase their shares mainly in order to distribute excess cash to shareholders (free cash flow hypothesis), to replace cash dividends due to tax considerations (excess capital hypothesis), to avoid hostile takeovers (takeover deterrence/management entrenchment hypothesis), to increase shareholders' wealth (wealth transfer hypothesis), to optimize capital structure (optimal leverage hypothesis), to increase employee motivation by means of stock options (management incentive hypothesis), and to send a signal to their investors regarding the profitability of the company or value of the shares and to stabilize price movements (signaling hypothesis) (Note 1).

Priority ranking of these motivations is subject to change depending on the common practice in jurisdictions. For instance, signaling (by means of increasing EPS and stock liquidity) ranks first in the UK (Grayston, 2012, p. 4); motivating and signaling go hand in hand in French (Jais \& Vidalenc, 2012, p. 3); and utilizing excess capital 
leads in the US (Habbart, Nolen, \& Cohen, 2012, p. 3) market.

The case in Turkey proves that signaling outshines others by far. Therefore, we believe that the market needs empirical evidence on the regulatory effects and this is a timely opportunity for a secondary research to be conducted in this area to analyse the effects of stock repurchase transactions on share prices in terms of performance, i.e. a common signaling metric, in Turkish capital markets.

Henceforth, we intend to test whether or not stock repurchases generate abnormal returns using standard event methodology. The outcomes of our analyses reveal that stock repurchases have a signaling effect on share prices in the short-term and managers are able to time stock repurchases in that respect. Signaling effect also manifests itself when investors' perceptions towards firm shares in terms of size and growth potential and special features of repurchase transaction such as frequency and expectancy are taken into account.

Under this backdrop, Section II portrays the literature regarding the conceptual framework of stock repurchase and gives some insight into Turkish legal infrastructure to trigger a comprehensive analysis. This analysis starts with Section III and Section IV that introduce the information about research data and methodology, respectively. Chapter V discusses the results of the analysis and Chapter VI concludes.

\section{Literature Review}

\subsection{Theoretical Implications}

Existing literature contains a rich amount of studies on the subject matter, however, a variety of answers under several hypothesis are produced depending on the given market characteristics and repurchase methods used. On the other hand, open market repurchases prove to be the most popular method used in almost all markets and the signaling feature of this method inherently requires comprehensive analysis of impacts of repurchase transaction on stock prices. In fact, Turkish market practice also shows that the most prominent motivations of managers behind open market stock repurchase is to avoid undervaluation and to reduce volatility which call for testing signaling hypothesis.

Stock repurchase may be used for signaling purposes as it is more flexible than cash dividends. That is to say, it enables management to signal whenever market conditions necessitate. On the other hand, signaling hypothesis is based on the desire of management to gain advantage on insider, i.e. asymmetric, information against shareholders. Stock repurchase allows managers to make use of two kinds of signaling: undervaluation of stocks and sending positive messages to investors.

The former is associated with the assumption that insider positions of managers give rise to an information asymmetry problem against shareholders which results in misvaluation of share prices in the market (Keown et al., 2004, p. 401). Managers believe that undervalued shares are positive net present value investments (Lie, 2005 , p. 414) and they send a strong signal to the market by stock repurchase that the most reasonable investment option is firm's shares. After investors begin to buy shares as a reaction to the signal, prices go up and undervaluation problem disappears.

As stock repurchase are used to recover price declines and to provide liquidity (Habbart, Nolen, \& Cohen, 2012, p. 3), it has recently been perceived as an appropriate corporate finance tool to support share prices (Wymeersch, 2006, p. 5). Literature shows a plenty of studies regarding the price effects of stock repurchases. From the performance point of view, research shows positive relationship between repurchases and abnormal returns. Especially, several research conducted in the US market by Vermaelen (1981), Netter and Mitchell (1989), Ikenberry, Lakonishok and Vermaelen (1995) and Liu and Ziebart (1997) emphasizes that share prices signicantly increase as a consequence of stock repurchases. Research outside the US market also reveals similar results. For instance, Ikenberry, Lakonishok and Vermaelen (2000) in Canadian market; Zhang (2005) in Hong Kong market; Hatakeda and Isagawa (2004) in Japanese market portray that repurchase transactions are related with price changes. Researchers believe that such price changes occur as the market perceives repurchases as positive signals or solutions for agency problems. More recently, Chua (2010), Chen and Wang (2012) and Liang et al. (2012) find that short-term price reactions to stock repurchases still exhibit a positive pattern in the US market. Bonaimé et al. (2014) intend to explore the relationship between market reactions to stock repurchases and capital structure policies and they find that underlevered and undervalued firms witness more reaction as opposed to overlevered and overvalued ones. Positive reaction to stock repurchase seems to be valid for the markets outside the US as well. Indeed, Manconi et al. (2014) show that in most of the 31 non-US jurisdictions, abnormal returns are significantly positive.

\subsection{Institutional Background}

Stock repurchases are important transactions that refer to corporate structure, corporate governance and 
corporate finance decisions. In fact, as the authority to use company funds for repurchase is delegated to managers, the company is exposed to the risk of loss in case managers exert their authority at their personal interests. Therefore, many jurisdictions have prohibited repurchases for years except for extraordinary cases (Andriosopoulos \& Hoque, 2013; Hatakeda \& Isagawa, 2004; Grayston, 2012).

Nevertheless, new regulations protecting creditors, shareholders and investors have recently replaced this prohibitive approach as it has been widely accepted that repurchases provide a flexible financial opportunity for companies. These new company law regulations require repurchases do not impede capital maintenance, be disclosed effectively, and do not deviate from the principle of equal treatment of shareholders.

Company law regulations are embedded in Turkish Commercial Code (TCC) in Turkish law system. TCC also consists of provisions on share repurchases. TCC had adopted a conservative approach in order to protect share capital and assets, in other words, creditors of the companies before. Indeed, specific provisions requiring that the share capital is committed, shares may not be issued below par, dividends may only be distributed from profits and unrestricted reserves, the value of capital in kind is appraised by experts appointed by courts, interests may not be paid to share capital had been regulated to keep company assets at least at the same level of share capital, which is a cushion for creditors. Therefore, share repurchases had been regarded as extraordinary transactions in the TCC.

However, this conservative approach, which is one of the characteristics of company law in Continental Europe, has been subject to removal as repurchases gained importance in satisfying companies' financial needs. In that respect, prohibitive regulations of old TCC in Turkey have been repealed in parallel with the regulatory improvements in the global arena, and have been revised in the new TCC (issued in 14.02.2011 and came into effect in 01.07.2012), which complies with EU acquis communitaire.

Following new TCC, capital markets experienced a radical change in Capital Markets Law (CML) that came into effect on 30.12.2012, and regulations regarding share repurchases are included in the law instead of handling the process by means of secondary legislation, i.e. board decisions.

Lastly, a new Capital Markets Board (CMB) regulation was issued on 03.01.2014 (CMB Regulation), which clearly defined principles regarding repurchases in a detailed way and necessary legal infrastructure was completed as a whole.

\section{Data}

The data set for this research is provided by Borsa Istanbul (BIST), Public Disclosure Platform (PDP) (Note 2) and CMB. In that respect, factual data on firms making stock repurchase transactions is obtained, from where it will be reviewed and verified by means of financial reports, e.g. financial statements, annual reports or audit reports, disclosed via PDP. Financial data pertaining to these transactions such as stock price is retrieved primarily from BIST, however FINNET (Note 3), Datastream and Thomson Reuters databases are also actively used in order to fine-tune the data in the analysis.

That Turkish regulations regarding stock repurchase are relatively new requires the research has a short-term nature in that only short-term effects of repurchases on share prices are analysed. Hence, the sample period extends from the third quarter of year 2010, i.e. 2010/q3, when first stock repurchase transaction (Note 4) is carried out to the last quarter of year 2013, i.e. 2013/q4, that is just before the newest CMB Regulation came in effect on January 3rd, 2014. Table 1 reports all firms (Note 5) that both announced their stock repurchase programs and repurchased their stocks accordingly within this sample period:

Though it is not reported in Table 1, of the 34 repurchasing firms, 14 firms are traded on the National Market; 7 firms are traded on Collective Products Market; 10 firms are traded on Second National Market; 1 firm is traded on Free Trade Platform, which are all together the sub-markets of BIST Equity Market and 2 firms are traded on BIST Emerging Companies Market (Note 6).

As is the case in most of the empirical studies, regulated financial institutions such as investment trusts (7) and brokerage houses (1) are excluded from the sampling process since they are generally subject to specific legislation and they may use stock repurchase with distinctive motivations. Banks are also regulated financial institutions, however they have never repurchased their stocks during the sampling period.

Since frequently repurchasing firms would bias the analysis, it is assumed that consecutive repurchases in a given month are deemed as a single transaction and the transaction in the first business day in that month is included in the calculations (Zhang, 2005, p. 1891). After excluding the ones that lack data (2) (Note 7) as well, finally, 24 firms with 97 (Note 8) observations are included in the analysis. 
Table 1. Number and amount of stock repurchases

\begin{tabular}{|c|c|c|c|c|}
\hline Main Industry & Sub-sector & $\begin{array}{l}\# \text { of } \\
\text { Firms }\end{array}$ & $\begin{array}{c}\text { \# of Stock Repurchase } \\
\text { Transactions (\%) }\end{array}$ & $\begin{array}{c}\text { Amount of Stock Repurchase } \\
\text { Transactions (\%) }\end{array}$ \\
\hline \multirow{5}{*}{ Manufacturing Industry } & $\begin{array}{c}\text { Textile, wearing apparel and } \\
\text { leather }\end{array}$ & 2 & 3,3 & 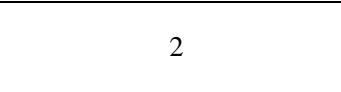 \\
\hline & $\begin{array}{l}\text { Chemicals, petroleum rubber } \\
\text { and plastic products }\end{array}$ & 3 & 3,4 & 2 \\
\hline & Food, beverage and tobacco & 2 & 1,2 & 0 \\
\hline & $\begin{array}{l}\text { Non-metallic mineral } \\
\text { products }\end{array}$ & 1 & 0 & 0 \\
\hline & $\begin{array}{l}\text { Fabricated metal products, } \\
\text { machinery and equipment }\end{array}$ & 1 & 1,3 & 0 \\
\hline Wholesale and Retail Trade, & Consumer trade & 1 & 2 & 3 \\
\hline Hotels and Restaurants & Restaurants and hotels & 3 & 4,2 & 1 \\
\hline Technology & Information technology & 2 & 17.2 & 2 \\
\hline $\begin{array}{l}\text { Transportation, } \\
\text { Telecommunication and Storage }\end{array}$ & Transportation & 1 & 0 & 0 \\
\hline $\begin{array}{c}\text { Professional, Scientific and } \\
\text { Technical Activities }\end{array}$ & $\begin{array}{l}\text { Legal and accounting } \\
\text { activities }\end{array}$ & 1 & 9 & 0 \\
\hline \multirow{4}{*}{ Financial Institutions } & Brokerage houses & 1 & 0 & 1 \\
\hline & Real estate investment trusts & 5 & 4,3 & 41 \\
\hline & Investment trusts & 2 & 8 & 1 \\
\hline & $\begin{array}{l}\text { Holding and investment } \\
\text { companies }\end{array}$ & 9 & 46.1 & 45 \\
\hline \multicolumn{2}{|c|}{ TOTAL } & 34 & 100 & 100 \\
\hline
\end{tabular}

Note. Table 1 shows that financial institutions (17) and manufacturing firms (9) overweigh on the basis of main industry while hold ings and investment companies (9) and real estate investment trusts (5) overweigh on the basis of sub-sector. Holdings and investment companies hold the biggest share in terms of the number (46\%) and amount (45\%) of stock repurchase transactions. Information technology firms and real estate investment trusts follow in terms of the number (17.2\%) and amount (41\%) of stock repurchases, respectively.

\section{Methodology}

It is worthwhile to analyse movements in stock prices after stock repurchase transactions since such transactions are at its infancy and not only firms themselves but also investors and regulatory bodies need reliable information to comprehend why stock repurchase is used and what its impacts/signals are in the market. For instance, that stock repurchase transactions enable investors to get abnormal returns would remind that repurchase decision is made as stocks are undervalued.

Therefore, the following hypothesis pursuing signaling effect in substance is formulated in accordance with the aforementioned literature review.

Hypothesis: Stock repurchase generates abnormal returns as share prices go up in Turkish capital markets.

Abnormal returns are measured by the error term obtained from the market model below (Beaver, Clarke, \& Wright, 1979).

$$
R_{i t}=\alpha_{i}+\beta_{i} R_{m t}+\varepsilon_{i}
$$

$R_{i t}$ is the rate of return of $\mathrm{i}$ share in t period; $R_{m t}$ is the rate of return of market portfolio (Note 9) in t period and $\varepsilon_{i t}$ is the abnormal return of $i$ share in $t$ period. Rate of returns for a single share in a single day is calculated in Excel by simply dividing the difference between the closing price at that single day and at that of the previous day by the share price of the previous day, i.e. $\left(t_{l}-t_{0}\right) / t_{0}$. Closing price information per each share is retrieved from several databases such as FINNET, Datastream and Thomson Reuters, comparatively. Coefficients, i.e. $\alpha_{i}$, $\beta_{i}$, are estimated by ordinary least squares method (OLS).

Cumulative abnormal returns (CAR), on the other hand, are calculated in Excel by the common function below (Zhang, 2005; Hatakeda \& Isagawa, 2004; Grullon \& Michaely, 2004; Weston \& Siu, 2002; Ikenberry, Lakonishok, \& Vermaelen, 1995):

$$
C A R_{\imath t}=\sum_{t=1}^{n} \varepsilon_{i t}
$$


In this study, event study methodology is conducted to analyse the abnormal returns around repurchase transactions.

An event study is concerned with the impact of an event on a specific dependant variable. In the majority of applications, a standard event study methodology is commonly associated with return analysis, where the dependant variable is the stock price of a company, manifesting itself in abnormal returns (Woon, 2004).

The methodology basically relies on market efficiency in that there is good reason to expect that impacts of an event will be reflected in stock prices in a short period of time in relatively efficient markets (MacKinlay, 1997). Hence, it is used to measure market efficiency and is very common in finance.

Given this background, this study implements a standard procedure similar to other event studies. First of all, this study defines "the event" as "actual stock repurchase transaction" in order to measure and interpret the results obtained for each hypothesis. $\mathrm{CMB}$ regulations uniquely require disclosure of stock repurchase transactions, so it is possible to analyse daily price movements which is generally not the case for other markets where repurchase announcements are mostly used instead of actual repurchases in the analyses. This is important because an announcement does not require the firm to repurchase its stocks, so it would be superficial to infer about the price effects of repurchases. That is why the transaction itself is of much greater interest than the announcement in this study. As repurchase transactions can be traced day-by-day, it is very convenient to distinguish the event days and the abnormal returns around these days. Afterwards, event windows are identified which include the exact day of stock repurchase transaction and allow to examine the impacts of it on prices before and after that date. In that respect, an event window of 41 business days $(-20,20)$ is opened as " 20 business days before" and "20 business days after" repurchase date, i.e. the event date, so as to measure short-term performance of share prices following repurchase. Then, data collection phase is concluded with regards to the firm selection criteria. Model parameters, i.e. variables, are estimated or calculated in the next step and univariate and multivariate analyses are carried out in conjunction.

In the case for univariate analysis of abnormal returns, three additional sub-windows, $(-20,-1),(0,1)$ and $(0,20)$, are opened to analyse and compare CAR within the main event window. In accordance with CMB regulations investors are able to have all information about each stock repurchase transaction in the following business day $(+1)$ at the latest. In practice, Turkish firms disclose stock repurchase transactions at the end of the same day or at the beginning of the following business day. The sub-window of $\operatorname{CAR}(0,1)$ is opened in order to uncover the initial reaction of the market to stock repurchase transactions. The sub-window of $\operatorname{CAR}(0,20)$ is opened in order to analyse mid-term price performance after stock repurchase. Returns pertaining to the past 100 business days $(-120,-21)$, i.e. estimation window, of each repurchasing firm are used to estimate the market model in CAR calculations. Parametric t-test and non-parametric tests are performed as a means of extending the validity of the findings, results of which are displayed in Table 4.

On the other hand, as investors' reactions may depend on their perceptions towards firm shares and special features of repurchase, the CAR sample is partitioned into three groups with respect to market capitalization (MCAP), Market Value/Book Value (MKBK), and some repurchase features (Ikenberry, Lakonishok, \& Vermaelen, 1995; Zhang, 2005). MCAP and MKBK are grouped based on quarterly information for firms retrieved from BIST; and, firms/observations to be included in each quarter are determined by proportioning their MCAP and MKBK by total MCAP and MKBK of all firms traded in BIST. In this regard, MCAP and MKBK groupings involve four levels each where firms are sorted smallest to largest as for the former and firms are sorted lowest to highest as for the latter. Repurchase features are partitioned into sub-groups that involve variables such as repurchase size and surprising notion of stock repurchase. In this regard, Zhang's (2005) methodology is followed, and the ratio of number of stocks repurchased to number of outstanding shares (RSIZE) is used in order to grab the signaling power; while number of days passed since last repurchase date (NDAYS) and number of repurchase in a quarter following the repurchase period (NP3M) are used in order to grab the surprising notion of repurchase. Groupings regarding these three variables are made in accordance with their median values. RSIZE, NDAYS and NP3M information is compiled from the repurchase transaction data available at PDP. The results of this complementary univariate analysis are displayed in Tables 5 and 6.

In the case of multivariate analysis, each variable is analysed separately by taking firm and repurchase characteristics into consideration. The following models are used in CAR analysis and estimated in accordance with OLS method in cross-sectional regression analysis:

$$
\begin{aligned}
\operatorname{CAR}(0,1)_{t} & =\beta_{1} \operatorname{CAR}(-20,-1)_{(t)}+\beta_{2} \operatorname{MCAP}_{(t)}+\beta_{3} \operatorname{MKBK}_{(t)}+\beta_{4} \operatorname{NDAYS}_{(t)}+\beta_{5} \operatorname{NP3M}_{(t)}+\beta_{6} \operatorname{RSIZE}_{(t)} \\
\operatorname{CAR}(0,20)_{t} & =\beta_{1} \operatorname{CAR}(-20,-1)_{(t)}+\beta_{2} \operatorname{MCAP}_{(t)}+\beta_{3} \operatorname{MKBK}_{(t)}+\beta_{4} \operatorname{NDAYS}_{(t)}+\beta_{5} \operatorname{NP3M}_{(t)}+\beta_{6} \operatorname{RSIZE}_{(t)}
\end{aligned}
$$


These models intend to measure which factors, i.e. independent variables, are associated with the abnormal returns after repurchase transactions, i.e. dependent variables. In this regard, $\operatorname{CAR}(0,1)$ and $\operatorname{CAR}(0,20)$ are dependent variables representing CAR in periods after event date. Of the independent variables, CAR(-20,-1) variable is included in the models in order to control the disturbing impact of negative CAR occurring before repurchase on the averages of dependent variables. Other independent variables are the ones already considered in the univariate analyses for CAR. Empirical results reveal the relationship between repurchases and abnormal returns as shown in Table 7.

Overall, event study methodology is followed to test basic price impacts, i.e. abnormal returns, of stock repurchase transactions and under this methodology both univariate and multivariate analyses are conducted to figure out the statistical and economical significance of these impacts, if any. Next section outlines the results following the application of the methods specified above.

\section{Results}

After deciding on the sample and collecting all relevant data for variables from secondary sources such as BIST, PDP, FINNET, Datastream and Thomson Reuters in order to apply the event study methodology, both univariate and multivariate analyses are performed with respect to the impact of repurchase on stock performance. So as to grasp whether stock performance is enhanced after repurchase transactions in Turkish capital markets, univariate analyses involve parametric and non-parametric tests that reveal performance behaviour against stock repurchase transactions. Multivariate analyses intend to strengthen the results of these univariate analyses. Hereby, first section describes the repurchase situation in Turkey in statistical terms whereas second section provides univariate and multivariate analyses for the hypothesis.

It is possible to argue that firms have not been familiar with CMB's first ever decision that allowed only brokerage firms and investment trusts to repurchase their stocks yet in the regulatory period of 01.09.2009-10.08.2011. However, following CMB's revised decision that extended the scope of the initial one to all listed companies, the market witnessed a considerable amount and volume of stock repurchase transactions. Figure 1 illustrates this improvement in the market with respect to the sampling period graphically.

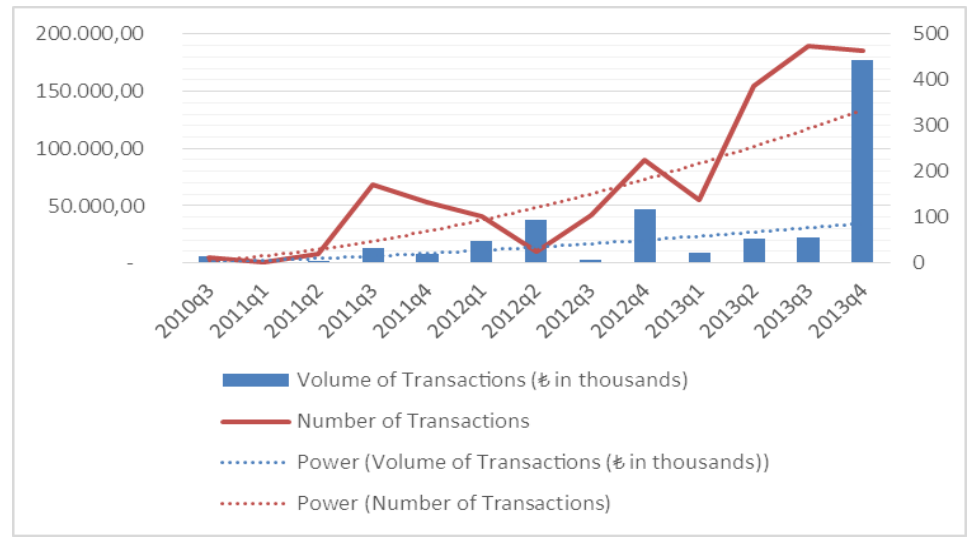

Figure 1. Stock repurchase transactions between 2010/q3 and 2013/q4

The increase in stock repurchase transactions can be traced as of the third quarter of year 2011, i.e. 2011/q3. The sharp increase in 2013/q4 is essentially due to the huge amounts of stock repurchase transactions carried out by a single large-size firm. The preceding graphical representation of stock repurchase transactions is detailed in Table 2 below: 
Table 2. Stock repurchase transactions between 2010/q3 and 2013/q4

\begin{tabular}{ccccc}
\hline Period & \# of Repurchasing Firms & $\begin{array}{c}\text { \# of Stock Repurchase } \\
\text { Transactions }\end{array}$ & $\begin{array}{c}\text { Volume of Stock Repurchase } \\
\text { Transactions (TLin thousands) }\end{array}$ & $\begin{array}{c}\text { Average Repurchase Rate } \\
(\%)\end{array}$ \\
\hline $2010 \mathrm{q}_{3}$ & 1 & 13 & $5.658,50$ & 0,82 \\
$2010 \mathrm{q}_{4}$ & - & - & - & 0,67 \\
$2011 \mathrm{q}_{1}$ & 1 & 3 & 148,56 & 8,10 \\
$2011 \mathrm{q}_{2}$ & 1 & 21 & $1.863,51$ & 4,44 \\
$2011 \mathrm{q}_{3}$ & 6 & 170 & $12.889,08$ & 10,58 \\
$2011 \mathrm{q}_{4}$ & 8 & 132 & $7.528,13$ & 0,92 \\
$2012 \mathrm{q}_{1}$ & 9 & 103 & $19.011,36$ & 1,06 \\
$2012 \mathrm{q}_{2}$ & 4 & 24 & $37.826,90$ & 0,63 \\
$2012 \mathrm{q}_{3}$ & 3 & 105 & $3.169,03$ & 1,57 \\
$2012 \mathrm{q}_{4}$ & 11 & 226 & $46.977,18$ & 1,01 \\
$2013 \mathrm{q}_{1}$ & 7 & 138 & $8.741,04$ & 1,36 \\
$2013 \mathrm{q}_{2}$ & 10 & 387 & $21.125,11$ & 0,92 \\
$2013 \mathrm{q}_{3}$ & 7 & 475 & $21.896,38$ & 1,03 \\
$2013 \mathrm{q}_{4}$ & 7 & 464 & $177.526,13$ & 2,37 \\
Mean & 5 & 162 & $26.025,78$ & 1,02 \\
Median & 7 & 119 & $10.815,06$ & - \\
Total & $75(34)$ & 2.261 & $364.360,91$ & \\
\hline
\end{tabular}

Data included in Table 2 is hand-collected from PDP where relevant information is disclosed by each repurchasing firms. The number of repurchasing firms shows duality since " 75 " represents the firms using stock repurchase several times among periods, while "34" represents the actual number of firms regardless of repetitions. Average repurchase rate is calculated by dividing par values of stocks repurchased by that of outstanding shares.

The most attractive point Table 2 is the prominent increase in the volume of stock repurchase transactions year-by-year. For instance, total volume in year 2013 (TL229.288.650) is almost ten folds of the one in year 2011 (TL22.430.280). Moreover, Table 2 shows that, on average (median), 5 (7) firms have made stock repurchase transactions 162 (119) times at an amount of TL26.000.000 (TL11.000.000).

On the other hand, firms should disclose the motivation behind stock repurchase in their repurchase programs in accordance with $\mathrm{CMB}$ regulations (Note 10). Table 3 portrays these motivations in Turkish capital markets:

Table 3. Repurchase motivations

\begin{tabular}{lcc}
\hline \multicolumn{1}{c}{ Motivation } & \# of Observations & Frequency of Observations (\%) \\
\hline Avoiding undervaluation & 49 & 45.9 \\
Reducing volatility by tracking price movements & 25 & 23.4 \\
Building trust with firm shares & 10 & 9.4 \\
Taking advantage of market conditions & 7 & 6.5 \\
Preventing investors from loss & 5 & 4.6 \\
Supporting share prices & 5 & 4.6 \\
Optimal allocation of firm's resources & 2 & 1.8 \\
Avoiding huge discounts on share prices & 2 & 1.8 \\
Contributing to stable and fair price formation & 1 & 1 \\
Being unable to meet dividend expectations due to rigid legislation & 1 & 1 \\
TOTAL & 107 & 100 \\
\hline
\end{tabular}

Table 3 is prepared after a careful examination of stock repurchase programs publicly disclosed by firms via PDP. It is worth to note that some firms have disclosed more than one program and repurchase programs of two firms have been inaccessible. As it is clear from Table 3, there appear to be one main reason why firms repurchase stock in Turkey has been "avoiding undervaluation $(45,9 \%)$ ". When "avoiding undervaluation" is linked to "building trust with firm shares $(9,4 \%)$ ", "avoiding huge discounts on share prices $(1,8 \%)$ " and "contributing to stable and fair price formation (1\%)", the original scores improves to $58,1 \%$, in essence. This factual data 
corresponds with signaling hypothesis discussed previously.

Henceforward, it is reasonable to analyse stock price performance around repurchases in order to make reliable interpretations about whether or not managers that decide to repurchase use shares as a right investment option, in other words, whether or not they are able to time (i.e. following share price declines) repurchases. Therefore, it would be possible to comment on the achievement of "avoiding undervaluation" goal which is associated with signaling hypothesis.

Table 4 portrays the daily average abnormal returns (AAR) and CAR information of repurchase firm shares within the event window of 41 business days. As it is clear from Table 4, a significant AAR $(0.947 \%)$ is obtained at the day $(+1)$ repurchase is publicly disclosed. In that respect, investors that buy the repurchase firm's share at the disclosure date would be able to gain almost $1 \%$ at the end of the day. In addition to results from a t-test, where $t$-value is the statistic to test the null hypothesis that $A A R=0$, the results of two supplementary non-parametric tests are also displayed in Table 4, which are Wilcoxon signed rank test and another signed test called $\mathrm{J}_{3}$ test (Note 11). These tests confirm that repurchase transactions have significant effects on AAR exactly at the disclosure date $(+1)$.

Results given in Table 4 point out that average CAR is significantly negative (-2.366\% and $-2.669 \%)$ (Note 12$)$ before $20(-20,-1)$ and $21(-20,0)$ business days before repurchase date $(0)$ and disclosure date $(+1)$. Therefore, it is apparent that prices significantly fall before the hike together with the disclosure. This can be interpreted as the market realizes stock repurchase and react only after the transaction is disclosed.

Table 4. Significance levels of average abnormal returns (whole sample)

\begin{tabular}{|c|c|c|c|c|c|}
\hline Day & AAR & CAR & t-value & Wilcoxon test & $\mathrm{J}_{3}$ test \\
\hline-20 & -0.326 & -0.326 & $-1.777 *$ & $-1.801 *$ & $-1.726^{*}$ \\
\hline-19 & 0.356 & 0.03 & 1.406 & -0.074 & -1.32 \\
\hline-18 & -0.395 & -0.366 & $-2.504 * *$ & $-3.233 * * *$ & $-2.741 * * *$ \\
\hline-17 & -0.221 & -0.587 & -1.109 & -1.387 & -0.711 \\
\hline-16 & 0.174 & -0.413 & 0.802 & -0.228 & -0.508 \\
\hline-15 & -0.036 & -0.449 & -0.143 & -0.995 & -1.117 \\
\hline-14 & -0.214 & -0.663 & -1.027 & $-2.463 * *$ & $-2.538 * *$ \\
\hline-13 & 0.04 & -0.623 & 0.234 & -0.193 & -0.102 \\
\hline-12 & -0.046 & -0.669 & -0.273 & -1.085 & -1.523 \\
\hline-11 & -0.471 & -1.14 & $-2.771 * * *$ & $-2.456^{* *}$ & $-2.132 * *$ \\
\hline-10 & -0.342 & -1.482 & -1.651 & $-2.661 * * *$ & -1.523 \\
\hline-9 & -0.122 & -1.604 & -0.556 & -1.333 & -1.32 \\
\hline-8 & 0.043 & -1.561 & 0.200 & -1.074 & -1.32 \\
\hline-7 & -0.333 & -1.894 & $-1.855^{*}$ & $-1.905^{*}$ & -1.523 \\
\hline-6 & -0.232 & -2.125 & -1.041 & -1.168 & -0.508 \\
\hline-5 & 0.138 & -1.987 & 0.533 & -0.027 & 0.508 \\
\hline-4 & 0.003 & -1.985 & 0.014 & -0.819 & -1.117 \\
\hline-3 & -0.036 & -2.02 & -0.156 & -0.354 & 0.102 \\
\hline-2 & 0.039 & -1.982 & 0.173 & -0.858 & 0.102 \\
\hline-1 & -0.385 & -2.366 & -1.413 & $-2.028^{*}$ & $-1.32 * *$ \\
\hline 0 & -0.303 & -2.669 & -0.928 & $-2.053 * *$ & $-2.538 * * *$ \\
\hline 1 & 0.947 & -1.722 & $3.071 * * *$ & $3.161 * * *$ & $2.741^{*}$ \\
\hline 2 & -0.268 & -1.99 & -1.211 & -1.384 & -1.929 \\
\hline 3 & -0.006 & -1.997 & -0.030 & 0.196 & -0.305 \\
\hline 4 & 0.529 & -1.468 & $2.225^{* *}$ & $1.787 *$ & 1.117 \\
\hline 5 & 0.309 & -1.16 & 1.129 & -0.279 & -0.711 \\
\hline 6 & 0.302 & -0.858 & 1.553 & 1.499 & 1.523 \\
\hline 7 & -0.112 & -0.97 & -0.538 & -1.096 & -0.508 \\
\hline 8 & 0.142 & -0.828 & 0.588 & -0.351 & 0.102 \\
\hline 9 & 0.364 & -0.464 & 1.469 & 0.455 & 0.305 \\
\hline 10 & -0.523 & -0.986 & $-2.395 * *$ & $-3.485^{* * *}$ & $-2.945^{* * * *}$ \\
\hline 11 & 0.088 & -0.899 & 0.322 & -1.150 & -0.914 \\
\hline 12 & 0.07 & -0.828 & 0.325 & -0.635 & -0.914 \\
\hline
\end{tabular}




\begin{tabular}{cccccc}
\hline 13 & -0.222 & -1.05 & -1.211 & $-1.855^{*}$ & -1.523 \\
14 & -0.246 & -1.296 & -1.309 & -1.607 & -1.117 \\
15 & 0.194 & -1.102 & 0.998 & 0.995 & 1.117 \\
16 & -0.13 & -1.232 & -0.709 & -0.779 & -1.117 \\
17 & -0.099 & -1.331 & -0.470 & -1.056 & $-1.929 *$ \\
18 & -0.206 & -1.537 & -1.141 & $-1.977^{* *}$ & $-2.335^{* *}$ \\
19 & -0.44 & -1.977 & $-2.077^{* *}$ & $-2.603 * * *$ & $-2.741^{* * *}$ \\
20 & -0.204 & -2.181 & -1.011 & -0.689 & 0.102 \\
\hline
\end{tabular}

Note: $* * *, * *$ and $*$ represent $0.01,0.05$ and 0.1 significance levels respectively.

Figure 2 pictures the CAR column in Table 4 as of the event window of $(-20,20)$ :

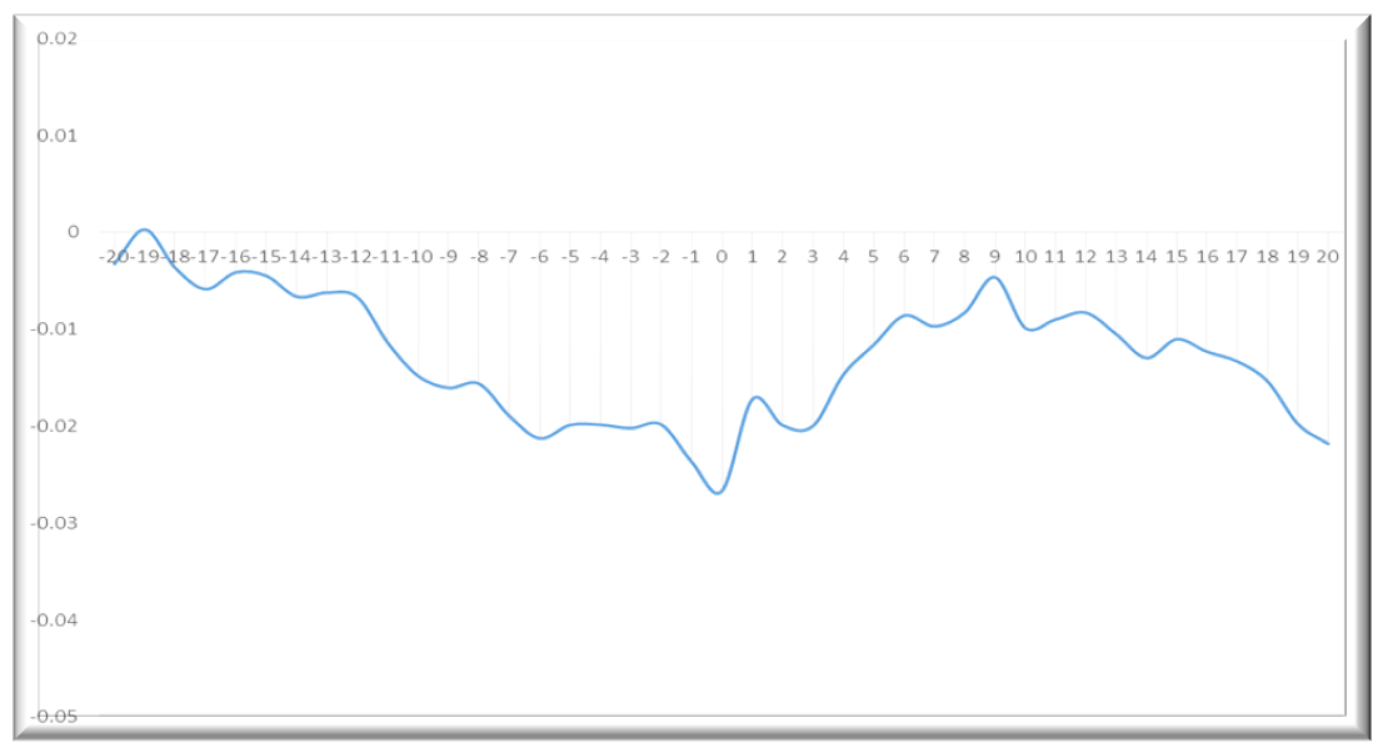

Figure 2. CAR graph $(-20,20)$

As can be seen from Figure 2, share prices of sample firms fall until the day stock repurchase is made (0), then go up hand in hand with the disclosure of the transaction. Afterwards, prices continue to rise $(1,9)$; hold for a while $(10,18)$, but fall in the end $(19,20)$. These results suggest that managers time stock repurchase in line with their opinion towards undervaluation and their signaling motivation.

Next, in order to take investors' perceptions towards firm shares and special features of repurchase into account, a further analysis is performed by grouping the CAR sample with respect to firm and repurchase criteria. CAR values of whole and grouped samples are reported separately as follows in Table 5:

In Table 5, Panel A shows that average CAR is significantly negative $(-2.366 \%)$ in the event window of $(-20,-1)$ which is similar with the previous findings. However, despite the fact that the significant AAR $(3.071 \%)$ (Note 13 ) is reflected positively on CAR in $(0,1)$ period, this reflection is not statistically significant. Indeed the economic impact is $0,644 \%$ which is low. Event window of $(0,20)$ produces similar results. On the other hand, this analysis is structured in accordance with the hypothesis that CAR of a given period is different from zero. When hypotheses comparing periods are set - e.g. CAR of $(0,1)$ and $(-20,-1)$ and of $(0,20)$ and $(-20,-1)$-, it is observed that CAR (positive) after repurchase is significantly different from the CAR (negative) before repurchase. 
Table 5. CAR significance levels (whole and grouped samples)

\begin{tabular}{|c|c|c|c|c|c|}
\hline \multicolumn{3}{|c|}{$\mathrm{N}$} & \multicolumn{3}{|c|}{ Event Window } \\
\hline PANEL A & \multirow{3}{*}{\multicolumn{2}{|c|}{97}} & $(-20,-1)$ & $(0,1)$ & $(0,20)$ \\
\hline CAR & & & -2.366 & 0.644 & 0.185 \\
\hline$p$-value & & & $0.018 * *$ & 0.178 & 0.875 \\
\hline PANEL B & $\mathrm{N}$ & & $(-20,-1)$ & $(0,1)$ & $(0,20)$ \\
\hline \multicolumn{6}{|l|}{ MCAP } \\
\hline CAR & \multirow[t]{2}{*}{10} & \multirow[t]{2}{*}{1 (smallest) } & -9.31 & 1.356 & 7.009 \\
\hline$p$-value & & & $0.009 * * *$ & 0.456 & $0.098 *$ \\
\hline CAR & \multirow[t]{2}{*}{39} & \multirow[t]{2}{*}{2 (relatively small) } & -3.23 & 0.835 & -0.19 \\
\hline$p$-value & & & $0.004 * * *$ & 0.257 & 0.9 \\
\hline CAR & \multirow[t]{2}{*}{39} & \multirow[t]{2}{*}{3 (relatively large) } & -0.32 & -0.41 & -2.54 \\
\hline$p$-value & & & 0.87 & 0.211 & 0.133 \\
\hline CAR & \multirow[t]{2}{*}{9} & \multirow[t]{2}{*}{4 (largest) } & 0.233 & 3.574 & 6.042 \\
\hline p-value & & & 0.923 & 0.305 & 0.374 \\
\hline \multicolumn{6}{|l|}{$M K B K$} \\
\hline CAR & \multirow[t]{2}{*}{10} & \multirow[t]{2}{*}{1 (lowest) } & -2.93 & 0.948 & -0.33 \\
\hline$p$-value & & & 0.523 & 0.678 & 0.952 \\
\hline CAR & \multirow[t]{2}{*}{39} & \multirow[t]{2}{*}{2 (relatively low) } & -1.07 & 0.094 & -1 \\
\hline$p$-value & & & 0.518 & 0.848 & 0.504 \\
\hline CAR & \multirow[t]{2}{*}{39} & \multirow[t]{2}{*}{3 (relatively high) } & -3.79 & -0.003 & 0.098 \\
\hline$p$-value & & & $0.005 * * *$ & 0.994 & 0.949 \\
\hline CAR & \multirow[t]{2}{*}{9} & \multirow[t]{2}{*}{4 (highest) } & -1.16 & 5.492 & 6.253 \\
\hline$p$-value & & & 0.699 & 0.141 & 0.378 \\
\hline \multicolumn{6}{|l|}{ NDAYS } \\
\hline CAR & \multirow[t]{2}{*}{51} & \multirow[t]{2}{*}{$\leq 28$} & -2.5 & 0.984 & 0.557 \\
\hline p-value & & & $0.065 *$ & 0.134 & 0.712 \\
\hline CAR & \multirow[t]{2}{*}{46} & \multirow[t]{2}{*}{$>28$} & -2.21 & 0.267 & -0.23 \\
\hline p-value & & & 0.139 & 0.706 & 0.902 \\
\hline \multicolumn{6}{|l|}{ NP3M } \\
\hline CAR & 49 & $\leq 11$ & -3.41 & 0.904 & 2.368 \\
\hline$p$-value & & & $0.021 * *$ & 0.29 & 0.255 \\
\hline CAR & 48 & $>11$ & -1.3 & 0.378 & -2.04 \\
\hline$p$-value & & & 0.338 & 0.379 & $0.053 *$ \\
\hline RSIZE & & & & & \\
\hline CAR & 46 & Low & -1.51 & 0.611 & 1.547 \\
\hline$p$-value & & & 0.245 & 0.371 & 0.356 \\
\hline CAR & 51 & High & -3.24 & 0.678 & -1.21 \\
\hline p-value & & & $0.035 * *$ & 0.318 & 0.467 \\
\hline
\end{tabular}

Note. $* * * * *$ and $*$ represent $0.01,0.05$ and 0.1 significance levels respectively.

Panel B of Table 5 portrays that small firms having high MKBK and repurchasing frequently, low in number of transactions and high in quantity repurchase their stocks in times when they are undervalued (MCAP: 9,31\% and 3,23\%; MKBK: 3,79\%; NDAYS: 2,5\%; NP3M: 3,41\%; RSIZE: 3,24\%). One can argue that investors react more positively to repurchase transactions made in shares of small firms $[7.009 \%$ in Panel B/MCAP for smallest firms in event window of $(0,20)]$. This is because information asymmetry is more apparent when small firm shares are considered. Moreover, it is possible to put that investors undervalue high MKBK firm shares as they believe that 
such firms are attractive ones in terms of their growth potentials and react positively, may be not statistically but economically significant $[6.253 \%$ in Panel B/MKBK for highest firms in event window of $(0,20)]$. This is a natural outcome of information asymmetry problem. In fact, literature justifies that information asymmetry is supposed to be more in high $M K B K$ firms (McLaughlin, Safieddine and Vasudevan, 1998). This point of view in the literature is based on the opinion that managers of high growth potential firms have more insider information about investment opportunities and future cash flows. On the other hand, even though managers repurchase more to send powerful signals (RSIZE) in times when shares are undervalued, initial positive reaction $[0.678 \%$ in Panel B/RSIZE for high firms in event window of $(0,1)]$ of investors turns into negative $[1.21 \%$ in Panel $B / R S I Z E$ for high firms in event window of $(0,20)]$ later on. Investors react to surprising repurchases (NDAYS) more positively [0.267\% in Panel B/NDAYS for $>28$ firms in event window of $(0,1)]$ than others; yet they do not like it any more $[0.23 \%$ in Panel B/NDAYS for $>28$ firms in event window of $(0,20)]$ after a while. Firms continuously repurchase (NP3M) are punished somehow in later periods [2.04\% in Panel B/NP3M for $>11$ firms in event window of $(0,20)]$.

Lastly, the results given in Panel A of Table 5 may be influenced by firms repurchasing more as some firms would like to repurchase more frequently while some firms would like to limit the number of repurchase transactions. Therefore, CAR data is recalculated based on number of firms rather than number of observations, and t-test results of 24 firms are portrayed in Table 6 below:

Table 6. CAR significance levels (whole sample based on number of firms)

\begin{tabular}{|c|c|c|c|c|}
\hline \multirow{2}{*}{\multicolumn{2}{|c|}{$\mathrm{N}$}} & \multicolumn{3}{|c|}{ Event Window } \\
\hline & & $(-20,-1)$ & $(0,1)$ & $(0,20)$ \\
\hline CAR & 24 & -3.675 & 1.84 & 2.712 \\
\hline$p$-value & & $0.036^{* *}$ & $0.091 *$ & 0.287 \\
\hline
\end{tabular}

Results in Table 6 seem to be consistent with those above in that stock repurchase transactions are carried out in times when shares are undervalued. Indeed, one can easily observe that share prices fall significantly $(3.675 \%)$ in the event window of $(-20,-1)$. However, initial reaction $(0,1)$ of investors after disclosure of repurchase is turned to be statistically and economically significant $(1.84 \%)$.

Thus, when effects of firms repurchased more frequently than others in the sample are controlled, it is easier to emphasize that the initial reaction of investors to repurchase is positive. In this framework, univariate analysis results clarify that managers time repurchase in that they repurchase at the point the shares are undervalued $(-20,-1)$, and initial reaction of investors at the time they are informed about the repurchase transaction $(0,1)$ is positive. Nonetheless, this positive impact disappears in time $(0,20)$.

It is important to interpret investors' reactions to stock repurchase by comparing multivariate analysis results with those of univariate analysis. Therefore, two different models put in the previous section are used in cross-sectional regression analysis so as to find out any factors affect abnormal returns after repurchase. Results of model estimations are reported in Table 7. In accordance with the given results, in spite of the control variable CAR(-20,-1), CAR of $(0,1)$ period is associated with MKBK and RSIZE; and CAR of $(0,20)$ period is associated with $M K B K$. However, coefficients of other independent variables are not significantly different from zero.

Table 7. Cross-sectional regression analysis

\begin{tabular}{|c|c|c|c|}
\hline \multirow[b]{2}{*}{ Independent Variables } & & \multicolumn{2}{|c|}{ Dependent Variables } \\
\hline & & $\operatorname{CAR}(0,1)$ & $\operatorname{CAR}(0,20)$ \\
\hline \multirow[t]{2}{*}{ Intercept } & Coefficient & -.0056 & .178 \\
\hline & $p$-value & 0.926 & 0.363 \\
\hline \multirow[t]{2}{*}{ CAR $(-20,-1)$} & Coefficient & .0535 & .246 \\
\hline & p-value & 0.256 & $0.081 *$ \\
\hline \multirow[t]{2}{*}{ MCAP } & Coefficient & .001 & -.009 \\
\hline & $p$-value & 0.868 & 0.425 \\
\hline$M K B K$ & Coefficient & .003 & .005 \\
\hline
\end{tabular}




\begin{tabular}{cccc}
\hline & $p$-value & $0.000 * * *$ & $0.011 * * *$ \\
Coefficient & $3.34 \times 10^{-5}$ & $1.01 \times 10^{-4}$ \\
$N$ NP3M & $p$-value & 0.666 & 0.297 \\
& Coefficient & $-6.97 \times 10^{-6}$ & $-1.07 \times 10^{-4}$ \\
RSIZE & $p$-value & 0.928 & 0.574 \\
& Coefficient & .027 & .004 \\
$\mathrm{R}^{2}$ & $p$-value & $0.001 * * *$ & 0.617 \\
F-value & & 0.244 & 0.15 \\
P-value & & 8.61 & 3.08 \\
$\mathrm{~N}$ & & $0.000 * * *$ & $0.004 * * *$ \\
\hline
\end{tabular}

Note. $* * *, * *$ and $*$ represent $0.01,0.05$ and 0.1 significance levels respectively.

On the other hand, even it is not statistically significant, that the coefficient of $M C A P$ regarding the event window of $(0,20)$ is negative is consistent with the previous results of univariate analysis in that investors react more to repurchases in small firm shares. Similarly, that the coefficients of $M K B K$ in both $(0,1)$ and $(0,20)$ periods are positive and significant again reveals that investors are more sensitive to repurchase transactions of firms possessing growth potentials. Lastly, that initial reaction of the market to excessive repurchases $(R S I Z E)$ is significant points out the signaling power of stock repurchase.

By and large, although coefficients are different in economic and statistical significance, univariate and multivariate analysis results complement each other and it is possible to conclude that analyses results are congruent with the ones obtained in the US (Vermaelen, 1981; Netter \& Mitchell, 1989; Ikenberry, Lakonishok, \& Vermaelen, 1995; Liu \& Ziebart, 1997), Canadian (Ikenberry, Lakonishok, \& Vermaelen, 2000), Hong Kong (Zhang, 2005) and Japanese (Hatakeda \& Isagawa, 2004) markets.

\section{Conclusions and Recommendations}

Stock repurchases, primarily open market stock repurchases, are important transactions in corporate finance when investment, financing and distribution decisions are in consideration (Wymeersch, 2006, p. 5). It has been widely accepted that stock repurchases provide a flexible financial opportunity for companies. Today, these transactions steadily increase in volume and become a common practice throughout the financial markets. Flexibility, when compared to dividends in particular, inherent in these transactions has had a critical role in regulatory changes in order to soften restricting provisions once-prevailing in capital markets.

Theory keeps tabs on practice in that there is an ongoing enrichment in literature that almost replaces the traditional studies have already been conducted for developed markets before with the new and more challenging ones focusing on other, e.g. emerging, capital markets. These studies mainly try to explain why stock repurchases are used under several assumptions namely free cash flow hypothesis, excess capital hypothesis, takeover deterrence/management entrenchment hypothesis, wealth transfer hypothesis, optimal leverage hypothesis, management incentive hypothesis and signaling hypothesis (Baker, Powell, \& Veit, 2003). Although these explanations have not produced a single answer to this very puzzle yet, a vast majority of studies still carry the intention to explore the price impacts of stock repurchase on firm value due to the direct link between signaling hypothesis, i.e. to send a signal to the market in order to avoid undervaluation, and stock prices in the market. Empirical investigations on stock performance lead these studies.

The basic assumption behind signaling hypothesis is that insider positions of managers give rise to an information asymmetry problem against shareholders which results in misvaluation of share prices in the market (Keown et al., 2004, p. 401). Managers tend to send signals to the market by stock repurchase in order for the investors perceive the signals as the most reasonable investment option is firm's shares. Accordingly, investors buy shares as a reaction to these signals and undervaluation problem disappears as a consequence.

Restrictive regulations in Turkey have also been subject to similar improvements pioneered by CMB which have recently ended up with a legal infrastructure that allows stock repurchases for publicly-held listed firms. This recent nature of Turkish regulations gives inspiration to make a research in the local market so as to analyse short-term price movements in the aftermath of regulatory improvements and to make inferences about initial market reaction to stock repurchase transactions.

Current market practice shows that the volume of stock repurchase transactions continuously increases in Turkey. Indeed, volume in year 2013 is almost ten folds of the one in year 2011. In addition to that, Turkish firms 
disclose that they use stock repurchase mainly to avoid undervaluation and reduce volatility which are proxies for signaling hypothesis. Thereby, there is good reason to specify the research question as "What are the price effects of stock repurchases in Turkish capital markets in the short-term?"

Based upon this short-term focused research question, hypothesis is formulated supporting the views that stock repurchase generates abnormal returns in Turkish capital markets. Following standard event study methodology within the sample period extending from the third quarter of year 2010, when first stock repurchase transaction is carried out to the last quarter of year 2013, that is just before the newest CMB Regulation came in effect, results obtained justify the hypothesis.

In this regard, the results show that there is a significant opportunity to generate abnormal returns after stock repurchase which indicates that stocks are repurchased primarily in order to avoid undervaluation. These results are reminiscent of those obtained in the US (Vermaelen, 1981; Netter \& Mitchell, 1989; Ikenberry, Lakonishok, \& Vermaelen, 1995; Liu \& Ziebart, 1997), Canadian (Ikenberry, Lakonishok, \& Vermaelen, 2000), Hong Kong (Zhang, 2005) and Japanese (Hatakeda \& Isagawa, 2004) markets.

Taken together, it is possible to make a final conclusion that undervaluation problem stems from information asymmetry both of which disappear seemingly after stock repurchase. In this regard, if timely and adequately used, stock repurchase may contribute to market efficiency. Otherwise, the regulatory bodies will have to face with negative reactions from investors which would deepen information asymmetry. Finally, corporate structures and growth potentials may also play a role in deciding to repurchase as firms that are small and possess high growth potential are more prone to information asymmetry which can be reduced by stock repurchase.

Recent Turkish regulations regarding stock repurchases need empirical support in order for the market to evaluate their success and this study is the first attempt intending to find reasonable answers about why Turkish firms use stock repurchase as a financial decision manifesting itself in stock price changes.

\section{References}

Andriosopoulos, D., \& Hoque, H. (2013). The Determinants of Share Repurchases in Europe. International Reivew of Financial Analysis, 27, 65-76. http://dx.doi.org/10.1016/j.irfa.2012.12.003

Baker, H. K., Powell, G. E., \& Veit, E. T. (2003, Autumn). Why Companies Use Open-Market Repurchases: A Managerial Perspective. The Quarterly Review of Economics and Finance, 43(3), 483-504. http://dx.doi.org/10.1016/S1062-9769(02)00151-5

Bonaimé, A. A., Öztekin, Ö., \& Warr, R. S. (2014). Capital Structure, Equity Mispricing, and Stock Repurchases. Journal of Corporate Finance, 26, 182-200. http://dx.doi.org/10.1016/j.jcorpfin.2014.03.007

Beaver, W., Clarke, R., \& Wright, W. F. (1979). The Association Between Unsytematic Security Returns and The Magnitude of Earnings Forecast Errors. Journal of Accounting Research, 17(2), 316-340. http://dx.doi.org/10.2307/2490507

Campbell, J. Y., Lo, A. W., \& MacKinley, A. (1997). The Econometrics of Financial Markets. Princeton, New Jersey, US A: Princeton University Press.

Chen, S. S., \& Wang, Y. (2012). Financial Constraints and Share Repurchases. Journal of Financial Economics, 105(2), 311-331. http://dx.doi.org/10.1016/j.jfineco.2012.03.003

Chua, J. M. (2010). Corporate Governance and Earnings Management Before Share Repurchase Announcements in Singapore. Master Thesis, Singapore Management University, Singapore. Retrieved 25 May, 2011, from http://ink.library.smu.edu.sg/etd_coll/60

De Jong, A., Van Dijk, R., \& Veld, C. (2003). The dividend and share repurchase policies of Canadian firms: Empirical evidence based on an alternative research design. International Review of Financial Analysis, 12, 349-377. http://dx.doi.org/10.1016/S1057-5219(03)00030-9

Dhanani, A., \& Roberts, R. (2009). Corporate Share Repurchases: The Perceptions and Practices of UK Financial Managers and Corporate Investors. Edinburgh: The Institute of Chartered Accountants of Scotland.

Grayston, C. (2012, May). International Bar Association. Corporate and M\&A Law Committee Treasury Shares Guide 2012 (England and Wales). Retrieved from http://www.ibanet.org/Article/Detail.aspx?ArticleUid=3AB49EE4-2A6C-413F-92C6-4C604422011E

Grullon, G., \& Michaely, R. (2004, April). The Information Content of Share Repurchase Programs. The Journal of Finance , 59(2), 651-680, http://dx.doi.org/10.1111/j.1540-6261.2004.00645.x 
Habbart, E. O., Nolen, S. A., \& Cohen, S. A. (2012, May). International Bar Association. Corporate and M\&A Law Committee Treasury Shares Guide 2012 (United States). Retrieved from http://www.ibanet.org/Article/Detail.aspx?ArticleUid=3AB49EE4-2A6C-413F-92C6-4C604422011E

Hatakeda, T., \& Isagawa, N. (2004). Stock Price Behavior Surrounding Stock Repurchase Announcements: Evidence from Japan. Pacific-Basin Finance Journal, 12, 271-290, http://dx.doi.org/10.1016/j.pacfin.2003.10.002

Ikenberry, D., Lakonishok, J., \& Vermaelen, T. (1995). Market Underreaction to Open Market Repurchases. Journal of Financial Economics, 39, 181-208, http://dx.doi.org/10.1016/0304-405X(95)00826-Z

Ikenberry, D., Lakonishok, J., \& Vermaelen, T. (2000). Share repurchases in Canada: Performance and strategic trading. Journal of Finance, 55(5), 2373-2397, http://dx.doi.org/10.1111/0022-1082.00291

Jais, P., \& Vidalenc, D. (2012, May). International Bar Association. Corporate and M\&A Law Committee $\begin{array}{lllll}\text { Treasury Shares } & \text { Guide } & 2012 & \text { (France). } & \text { Retrieved }\end{array}$ http://www.ibanet.org/Article/Detail.aspx?ArticleUid=3AB49EE4-2A6C-413F-92C6-4C604422011E

Keown, A., Martin, J. D., Petty, W. J., \& Scott, D. F. (2004). Foundations of Finance: The Logic and Practice of Financial Management (4th ed.). China: Pearson Education Asia Ltd. and Tsinghua University Press.

Kooli, M., \& L'Her, J. F. (2010, February). Dividends versus Share Repurchases Evidence from Canada: 1985-2003. The Financial Review, 45(1), 57-81. http://dx.doi.org/10.1111/j.1540-6288.2009.00237.x

Liang, W. L., Chan, K., Lai, W. H., \& Wang, Y. (2012). Motivation for Repurchases: A Life Cycle Explanation. Journal of Financial Services Research.

Liu, C. S., \& Ziebart, D. A. (1997). Stock returns and open-market stock repurchase announcements. Financial Review, 32(4), 709-728. http://dx.doi.org/10.1111/j.1540-6288.1997.tb00907.x

MacGuigan, J. R., Kretlow, W. J., \& Moyer, R. C. (2009). Contemporary Corporate Finance (11th ed.). Mason, Ohio, USA: South-Western Cengage Learning.

MacKinlay, A. C. (1997, March). Event Studies in Economics and Finance. Journal of Economic Literature, 35(1), 13-39.

Manconi, A., Peyer, U., \& Vermaelen, T. (2011). Buybacks Around the World. Available at SSRN 2330807

McLaughlin, R., Safieddine, A., \& Vasudevan, G. K. (1998, Summer). The Information Content of Corporate Offerings of Seasoned Securities: An Empirical Analysis. Financial Management, 27(2), 31-45. http://dx.doi.org/10.2307/3666291

Mieczysław, K. (2011). Share repurchases as a form of payout for shareholders. e-Finance: Financial Internet Quarterly, 7(4), 37-54.

Nayar, N., Singh, A. K., \& Zebedee, A. A. (2008, Summer). Share Repurchase Offers and Liquidity: An Examination of Temporary and Permanent Effects. Financial Management, 251-270. http://dx.doi.org/10.1111/j.1755-053X.2008.00012.x

Netter, J. M., \& Mitchell, M. L. (1989, Autumn). Stock-repurchase announcements and insider transactions after the October 1987 Stock Market crash. Financial Management, 18(3), 84-96. http://dx.doi.org/10.2307/3665651

Vermaelen, T. (1981, June). Common Stock Repurchases and Market Signaling: An Empirical Study. Journal of Financial Economics, 9(2), 139-183. http://dx.doi.org/10.1016/0304-405X(81)90011-8

Weston, F. J., \& Siu, J. A. (2002, December 19). Changing Motives for Share Repurchases. eScholarship University of California: Retrieved from http://escholarship.org/uc/item/9146588t

Woon, W. (2004). Introduction to Event Study Methodology. Singapore Management University.

Wymeersch, E. (2006). Reforming the Second Company Law Directive. Gent: Financial Law Institute.

Zhang, H. (2005). Share price performance following actual share repurchases. Journal of Banking \& Finance, 29, 1887-1901. http://dx.doi.org/10.1016/j.jbankfin.2004.06.038

\section{Notes}

Note 1. See (Baker, Powell, \& Veit, 2003) and the references therein. 
Note 2. PDP is an electronic system through which electronically signed notifications required by CMB and BIST regulations are publicly disclosed.

Note 3. FINNET stands for Financial Information News Network. This is a database company which develops research and analysis tools for capital and money markets in order to meet information needs of institutional and individual users.

Note 4. A real estate investment trust repurchased its stocks exactly on July 14th, 2010.

Note 5. However, there are other 14 firms that did not repurchased their stocks even though they had announced their stock repurchase programs before.

Note 6. National Market involves firms that meet listing criteria as a whole. Collective Products Market is a trading platform for investment trusts. Small and medium sized entities or other firms that are delisted from the National Market are traded on the Second National Market. Free Trade Platform is a market for specific firms decided by $\mathrm{CMB}$ with respect to their financial situations and/or ownership structures. Emerging Companies Market is a trading platform for firms that possess a growth potential but do not meet listing criteria.

Note 7. Both of these firms operate in the manufacturing industry and they lack data because of their recent foundations.

Note 8 . The original number of stock repurchase observations for 24 firms is 578 . However, as some of these transactions are carried out consecutively, i.e. day after day, Zhang's methodology used here drops the number of observations to 97.

Note 9. BIST 100 index is assumed to be the market benchmark in Turkish capital markets as it comprises the whole market in terms of market capitalization.

Note 10. [CMB Regulation, Art. 8/1-(a)]

Note 11 . This test is based on the assumption that the probability of positive or negative abnormal return is $50 \%$. In that, null hypothesis is $\mathrm{H0}: \mathrm{p} \geq 0.5$; alternative hypothesis is Ha: $\mathrm{p}<0.5$ where $\mathrm{p}$ is the probability of abnormal return is positive. Statistical metric, J3 is calculated as follows:

$$
J_{3}=\left[\frac{N^{+}}{N}-0.5\right] \frac{N \frac{1}{2}}{0.5} \sim N(0,1)
$$

$\mathrm{N}^{+}$is the number of positive abnormal returns, while $\mathrm{N}$ is total abnormal returns (Campbell et al., 1997, p. 172).

Note 12 . $t$ values are -2.413 and -2.367 respectively and significant at 0.05 significance level.

Note 13. see Table 4.

\section{Copyrights}

Copyright for this article is retained by the author(s), with first publication rights granted to the journal.

This is an open-access article distributed under the terms and conditions of the Creative Commons Attribution license (http://creativecommons.org/licenses/by/3.0/). 